\title{
Retrospection on Philosophy of Education of Gandhi, Vivekananda and Tagore for Futuristic Indian Education System: A Possibility!
}

\author{
Amita Valmiki \\ Ph.D., Associate Professor and Head, Department of Philosophy, Ramniranjan Jhunjhunwala \\ College (Affiliated to University of Mumbai), Mumbai (India) \\ E-mail: amitavalmiki@gmail.com
}

ORCID: 0000-0002-1235-3730

This article is a search for, if not ideal, at least a decent pedagogy in India. India is at the threshold of modernity and post-modern conflict. From Kindergarten to Post-Graduation (that is from KG to PG) a student is in a state of obscurity and uncertainty.

The question is - does India, a land of diversity and great civilization, lack philosophy of education that can be practically workable, vocationally satisfying (to cater the need of large population) and spiritually enriching? The answer is big a 'NO'. To name a few master thinkers and social reformers who believed that education is the only means to 'real progress' that is physical, mental, social and spiritual ascendance - namely Jyotiba Phule, Savitribai Phule, M. K. Gandhi, Sarvapalli Radhakrishnan, Swami Vivekananda, Sri Aurobindo, Rabindranath Tagore, Annie Besant, B. R. Ambedkar and many more. But, still the education system in India remains in apathy.

If not all, at least three of the prominent reformers that I find very impressive are Gandhi, Vivekanada and Tagore. (The order should not be taken seriously.) Their philosophy of education has been very reformative, innovative and apt for Indian culture since India lives in a complicated diversity. Since India lives in her diversity, the education system stands on a very fragile ground. There is a need to rejuvenate the system with transparency, acceptability and tolerance. All three thinkers mentioned in the article have shown one of these or all above three criteria in the realm of pedagogy. Our education system can do wonders if the 'intentional ethics' (keeping the axiology in mind) and 'ethos of the people' are combined together. Therefore, the future of Indian philosophy of education is not bleak if we transfer these reformists'ideas in our education system, indeed in new attire that is the need of the time.

Keywords: education system, primary education, higher education, vocational education, reformation, unity in diversity, transparency, acceptability, tolerance, naturalism, pragmatism

Received: September 27, 2018; accepted: October 3, 2018

Future Human Image, Volume 10, 2018: 103-111.

DOI: $10.29202 /$ fhi/10/11

(C) Valmiki, Amita, 2018 


\section{Introduction}

Education in India is on the threshold of modern and postmodern divide. The modern incorporates the perverted form of ancient and medieval educational system; and the postmodern incorporates undefined freedom, reckless liberalism and raw and rude naturalism. From Kindergarten to Post-Graduation (that is from KG to PG) the student was, is and remains confused.

The confusion is mainly due to ambiguity in understanding the term "education". Does it mean to learn to read and write? Or learning some skill or have vocational training to earn for your living? Or does it give knowledge of self or lead to self-realization? India is a land of many religions, races, languages, castes and clans. They have their variegated ways to define the system of education. According to John Dewey, "Education, in its broadest sense, is the means of this social continuity of life." [Dewey, 1916: p. 03]. Therefore, each group has a vested interest in maintaining their dignity and continuing the tradition of their distinct group. This obviously relates to high-level politics, economy and social aspect of their unique group.

However, in very simple terms what does education mean? As we are aware, it comes from Latin word 'Educatum', meaning 'to bring up' or 'to nourish'. It also means 'to find out' or 'to draw out'. It thereby implies 'effort is to draw out' rather than 'to put in'. Nevertheless, one more meaning is drawn from the word 'educatum', that is, 'act of teaching or training' [Rather, 2007: 01-02].

To wrap the introduction, in India education system lays in chaotic state. As we say 'history is written by winners'; so also in India educational policies are controlled, defined and regulated by the ruling political parties (in contemporary times). Does India lack thinkers and reformers who could give an ideal form of education system? Of course India has produced great philosophers, mystics, saints, thinkers and reformers who have contributed to ideal educational philosophy; in ancient, medieval, pre-British to post-British period. To name the few of them - Buddha, Adi Sankaracharya, Jyotiba Phule, Savitribai Phule, M. K. Gandhi, Sarvapalli Radhakrishnan, Swami Vivekananda, Sri Aurobindo, Rabindranath Tagore, Annie Besant, B. R. Ambedkar and many more. But still the education system in India remains in apathy.

In this article I tried to analyze the erudition brought about by three great reformers' philosophy of education that I feel is most needed in contemporary India - they are, namely Gandhi, Vivekananda and Tagore. If India today can retrospect the educational philosophies of these thinkers, put modern garb on it and implement it, then may be the axiological relevance of education will be realized and though not the utopian society, but at least pursuit of humanitarian society can be achieved. Indeed their educational philosophy not only comprised of axiology but also of metaphysics and epistemology.

\section{The Need for Intervention in the Field of Education in India}

Schools, colleges and universities provide an opportunity to unfold one's potentials and place an individual on the path of self-realization. The Right to Education (RTE) is the basic Constitutional right of every child in India. "In a 2011 decision the Supreme Court stated that, 'the right to children free and compulsory education has been made a fundamental right under Article 21A of the Constitution. Now every child of the age of 6 to 14 years has right to have free education in neighborhood school till elementary education." [Ahmad, 2016]. As such in post-British rule, lot of emphasis was given on primary or elementary education. 
However, unfortunately the secondary and higher education sector remain either neglected or undermined. Education in India, as noted earlier, is directly connected to her culture, economy and mainly politics.

As such, the first Constitution in independent India was implemented on January 26, 1950 that declared India as a Sovereign Socialist Secular Democratic Republic. Many amendments came in the due course of time in many Constitutional Articles. In relation to education, many provisions were made keeping in mind the following seven criteria:

1. Equality before law.

2. Religious instruction.

3. Interests in minorities.

4. Free and compulsory primary education.

5. Education of Schedule Castes and Schedule Tribes and other weaker sections.

6. Medium of instruction at primary stage. And

7. Centre-State relation relating to education [Dash, 2004: 02].

It seems none of the above mentioned seven criteria are implemented in its true sense. Officially, things are accepted as mentioned in the Constitution. But if one visits any village in India, the lower caste children are denied education, the tribals are out of it completely; medium of instruction has to be the State language, i.e. vernacular or regional language so that the child is at ease to communicate, but the craze for English is too high that today even the government run public schools, those initially adopted State language, started English medium schools. The flaws remain at all levels of primary education. The problems remain unsolved at primary level, the ideal for secondary and higher education still remains a mirage. Therefore, there is a need for serious intervention. The thinkers and activists like Gandhi, Vivekananda and Tagore espoused for a decent and viable education system.

\section{Mohandas Karamchand Gandhi (1869-1948)}

Gandhi, the propounder of Civil Disobedience Movement, Non-Co-operation Movement, Swaraj (Home Rule), Sarvodaya (Universal Uplift), Swadeshi (Home Production), and upheld steadfast Satyagraha (holding firmly on to Truth) and Ahimsa (Non-Violence), the man called as Mahatma (Great Soul) and Father of the Nation (of India); who all through his life believed in the philosophy of world solidarity contributed immensely to espouse for a good education system. Gandhi was a pragmatist; therefore, his idealism was always metamorphosized into praxis. According to him reading and writing is not the only way education can be defined. Education can create good and ideal citizens for the society. In fact, the United Nations when developed their literacy missions, incorporated Gandhi's basic educational policies [Kuriakose, 1995].

Gandhi believed in the ideology that individual development and development of the country go hand-in-hand; and to bring about this teleos, this goal (though I never found him a 'teleologist' as many believed he was; but always a 'deontologist' as he believed in the holy scripture of the Hindus, the Bhagavad Gita philosophy of Nishkamakarma i.e. 'duty for duty's sake'), education is the only instrument. So the aim of education is manifold according to Gandhi - self-realization, knowledge of the Absolute (name it God) and cultural refinement by constructing better human being. Gandhi also believed that education has to be selfsupporting; that is a student should have initially free education up to the age of 14 years (that is up to 7 th grade) and should be taught some occupation so that s/he can fund oneself 
for higher education. This will not only make the student literate, but also learn some skill; some craft to get materialize in some profession in future. According to him, teacher-student relationship is of utmost importance. A teacher has to be spiritually oriented and can further encourage students to develop good character. Without value-education no education can be said to be complete. This incorporated self-discipline, sacrifice, co-operation, excellence, truthfulness, non-violence, fearlessness etc. According to his concept of Nai-Talim (literally means 'New Education'), that is imbibed in the idea - 'basic education for all' and this target can be achieved only in one's mother-tongue (in local or regional language). The Britishers had their own agenda while providing education to Indians in English language; to create the community of 'clerks' for their benefit. However, Indians too, wanted to be equal to the Britishers by communicating in English and raising their dignity in society. In this matter, Gandhi was not against English language, or in that matter, against any language. But foreign language like English can defeat the whole pedagogical purpose in India. The nuances of the culture, to communicate ideas and for self-realization by building character - all these becomes impossible to achieve without one's regional language. Therefore, education in one's own mother-tongue would benefit not only the individual but the whole nation. In addition, most importantly Gandhi mentioned that higher education should not be expansive or should not be even a burden to taxpayers. Higher education should be available to all at very low cost [Bharathi, 1991: 44-45].

However, Gandhi's philosophy of education invites some criticism as well. Firstly, it is too ambitious. Secondly, the self-sufficiency or self-supporting education can lead to exploitation of children at the hands of their elders and this may lead to child abuse (as India is a poor country). Thirdly, Gandhi should have elaborated more about higher education too as Indian universities at present remains in shambles.

However, Gandhi was a visionary. Apart from these shortcomings, he has been a great reformist in matter of all the spheres of human life, education being most important. In Harijan (May 27, 1939) Gandhi wrote, "I value individual freedom, but you must not forget that man is essentially a social being. He has risen to his present status by learning to adjust his individualism to the requirements of social progress. Unrestricted individualism is the law of the beast of the jungle" [Gandhi, 1939]. Therefore, in his philosophy of life, education plays a pivotal role.

\section{Swami Vivekanada (1863-1902)}

Coming to another great visionary and reformer, the founder of Ramkrishna Mission, Swami Vivekananda - who was the disciple of the great mystic Ramkrishna Paramhansa (1836-1886) contributed immensely to bring forth 'inter-faith dialogue' and 'reviving Vedanta philosophy' (philosophy of Non-Dualism or philosophy of Monism; also called the Upanishads) and Yoga philosophy with help of reason. He was a philosopher par excellence. He introduced to the West the importance of Hinduism as a vital religious force during the late 19th Century. "(He was a) Hindu spiritual leader and reformer in India who attempted to combine Indian spirituality with Western material progress, maintaining that the two supplemented and complimented one another. His Absolute was a person's own higher self; to labour for the benefit of humanity was the noblest endeavour." [Encyclopedia Britannica, 2018].

According to Vivekananda, like Gandhi, spoke on building character of the student by instilling values in him/her. Like Gandhi, he believed that student should be self-sufficient and 
education should bring about confidence and respect among students. For this Vivekananda believed the education system in India should be the amalgamation of ancient Indian philosophy and modern Western ideologies. He believed in overall development of the masses, including women - their physical, mental, moral, spiritual and vocational development; and this can be achieved only through education. Vivekananda was an idealist, pragmatist and a naturalist [Prathapan, 2014]:

a) As an idealist, he insisted that the aim of education was to develop the child with moral and spiritual qualities.

b) As a pragmatist, he emphasized the need of Western education of technology, commerce, industry and sciences to achieve material prosperity.

c) As a naturalist, he emphasized that real education is possible only through nature and natural propensities.

Vivekananda can be described as, (according to Prof. B. K. Sarkar) 'father of modern materialism in India' [Bharata, 1939]. Indian philosophy, especially the Samkhya philosophy (one of the six systems of orthodox Vedic schools) believes in two ultimate entities in creation of the world; and both are indispensable. These are Purusha (Soul or Self that is conscious; and Prakrti (Matter that is unconscious). Most of the people believe in the sacred Purusha as Ultimate and undermine the importance of matter as impure as it is mundane and unconscious. Samkhya philosophy dispels this myth by making both as indispensable. Vivekananda, (though a Vedantin), like Samkhya philosophy tries to erase this ignorance and considered knowledge of material sciences equally important as science of self or soul. [Dasgupta \& Dasgupta, 1991].

Vivekananda strongly upheld the philosophy of Karma Yoga (the path of action) for young generation though he believed in other three paths as well, namely - Jñanna Yoga (the path of knowledge), Bhakti Yoga (the path of devotion) and Raj Yoga (the path of meditation). Just being a renunciate or remaining in seclusion does not provide solution to the problems of the world. One has to be actively participating in the scheme of this social life. Vivekananda himself was a celibate, but he actively participated in his founded Ramkrishna Mission. Vivekananda strongly believed that morality and religion are same. Therefore, a sound education system should incorporate religious education. Of course he believed in unity of all religions of the world; so the essence of religion is not to produce a divide but to construct assimilation. Though he spoke of 'Universality of Religion', he can be criticized on the ground that ultimately he upheld Vedic, Upanishadic (Vedantic) and the Bhagavad Gita philosophy that which has to be introduced in Indian education system. He was a Vedantin, to incorporate world religions in one course of the education and also to emphasize on Vedantic philosophy is a contradiction in terms. However, his approach to Vedantic philosophy is not emotional but rational.

Like Gandhi, he believed in education of technology, but present education system according to both of them in their times (and in present times also) is making human being slave of machines. Education for him should develop self-confidence and self-reliance among the youth of India. In addition, how is one to achieve this? He said by means of "love". He believed, "Love in the minds of the educator is the real source of his influence upon the education.....The child should be taught through love, fellow feelings and love for human beings. Education must help the individual to recognize his cultural heritage and to use it in his struggle of life. Education is a life-long process towards the fullest development of human 
personality, self-discovery, self-perfection, self-awareness and self-manifestation" [Barman, 2016: 107-108]. In every area of human life, education has to be an inevitable role to play according to Vivekananda. Therefore, if the students do not come to teacher, then teachers are supposed to go to students. However, the spread of education is a necessary and vital element for nation building.

To sum up Vivekananda's philosophy of education is he believed that the sole aim of education is "man-making." In the book Educational Philosophy of Swami Vivekananda, the authors have given following points as Swami Vivekananda's methods of teaching and learning, "Vivekananda was in favour of Indian system of educational organization which was based on the criteria of learning by sitting at the feet of the Archarya, Guru or the teacher, through a close contact. For this control or discipline of mind and body are important and Vivekananda suggested 'Concentration and Meditation, Brahmacharya (Celibacy), Faith, Reverence, Discussion, Study of Scriptures, Guidance, Service in to others, Congenial atmosphere based on freedom and discipline'. The success of education, according to Vivekananda, depends upon the initiative taken by the teacher in enthusing the child towards study, self-confidence, self-realization and self-reliance" [Bharathi \& Rao, 2005: 41]. Therefore, the curriculum or syllabus should not just comprise of facts but facts should be collected after learning the method of concentration of mind and develop anāsakti (that is detachment). His curriculum included knowledge of Eastern philosophy and technology along with Western sciences and technology. For him there cannot be any rigidity in syllabus but when Eastern philosophy and Western thought is brought together, it will definitely produce fruitful results.

\section{Rabindranath Tagore (1861-1941)}

Gurudev Rabindranath Tagore was a poet, painter, dramatist, actor, musician, and a naturalist mystic, an incredibly distinct personality who gave India's national anthem, who authored the book Gitanjali on which he was conferred the Nobel Prize in 1913.

Tagore believed in the concept of 'freedom'; where he believed that mind, knowledge and nation has to be free. Therefore education should enhance the 'creativity' which is dormant in every child, every individual. Unfortunately, our current (in pre-British rule and till date) education system was/is just mechanical teaching the sterile physical facts. Therefore, creativity is possible if the student values nature and elements of nature. For this humane tendency has to be developed through education. This can be achieved according to Tagore through idealism and internationalism. Therefore, he aspired to develop an institute based on the following four basic 'isms'. "There are four fundamental principles in Tagore's educational philosophy; naturalism, humanism, internationalism and idealism. Shantiniketan and Visva Bharathi (Tagore is founder of this university in West Bengal, India) are both based on these very principles" [Thriveni, 2018].

The present day education is unable to give knowledge of the higher level of consciousness, creativity through finer sensibilities. This one finds in Tagore's educational philosophy. There is definitely, according to Tagore a symphony, a chord, a rhythm between individual and society; education just has to restore this harmony among students [Chakrabarti, 1988]. Why Tagore emphasized on this 'harmony'? Because, according to him, India 'lives in unity in diversity'. India is a land of different races, religions and languages; if it still continues to live in harmony is not because of its historical inheritance through maturity; but through some 'deepest connection'. India lives in solidarity with the whole world. 
Tagore believed that it is important to bring about fusion of tradition and modernity in our education system. Therefore, he never upheld blindly accepted age-old Indian philosophy of education by being a pseudo nationalist; but like Vivekananda, he thought to take whatever is best from East and West (east mainly comprising of Indian tradition and west comprising of British education system.) As Ranjan Ghosh notes, "Without encouraging emotionalism in excess, his 'nationalism' would problematise the communication corridors which it could possibly engineer with the 'greater' world by his bharat chinta (thoughts about India, home) as meaningfully integrated with viswachinta (thoughts about the world)." [Ghosh, 2017: 24]. Therefore, by accepting pseudo nationalism, Swadeshi (home production) and Swaraj (homerule), according to Tagore the whole of education system in India suffered. This made him deviate from Gandhi who strongly supported the above-mentioned factors for India (though Gandhi was not pseudo nationalist). Gandhi was a political reformist also; while Tagore was a poet and an artist. (Gandhi has been true to his self as he fought vehemently imperialism; while Tagore did oppose imperialism; but his was a saintly and creative approach. Therefore, their philosophies also influenced their philosophy of education. Probably, in India we need to suffuse both their philosophies to bring about a decent education system.) Tagore believed that one has to accept what is 'genuinely good'. So, if India had great philosophy, it is the West, the British rule that gave unique 'philosophy of rationalism'. (Again, this reminds of Vivekananda.) Therefore, East and West, both need to be assimilated in Indian education system according to Tagore. Therefore, he gave Visvabharati University at Shantiniketan at West Bengal. Visvabharati means 'Communion of the world with India'. (This reminds of 'dialogical communication' and the urgent need of it by Karl Jaspers and Martin Buber's 'I-It' and 'I-Thou' relationship - the German Theistic Existentialists.) Visvabharti is like a Gurukul, completely being in 'natural surrounding' with open classrooms and giving the feeling of being one with nature and ultimately with the world.

\section{Conclusions}

The need is seriously felt of innovation, renovation and reformation in Indian education system. Gandhi, Vivekananda and Tagore's philosophy with some contemporary attire on it can do the needful. In a country like India education is an important realm of research for sociologists and social philosophers. Since India lives in its diversity, our education system stands on a very fragile ground. There is a need to rejuvenate the system with transparency, acceptability and tolerance (in present times, instead of tolerance we speak of 'patience'). All three thinkers mentioned in this article have shown one of these or all three criteria in the realm of education.

'Transparency' is obvious in Tagore as he talks of connecting India to the whole world. Unless and until one is transparent to one's own country's philosophical thinking - with its plus points and negative points, one will not be able to connect to the world and will remain (as in India it is popularly known) 'frogs of the well, but not of the ocean'.

In Vivekananda, 'acceptability' of Western philosophical tradition with Indian philosophical heritage is very important. He talks of rational approach that is quite Western in nature in amalgamation with Indian philosophical tradition. He upholds Vedanta philosophy but not without critical thinking and analysis.

Gandhi is known for his philosophy of 'tolerance', (in present scenario, we can say 'patience' as discussed earlier). If India has to live in peace, her education system must imbibe the concept of tolerance (patience). 
Therefore the education system in India needs to add in its curriculum subjects like Comparative Study of Religions, Linguistics and Linguistic Analysis and Study of Indian Culture in comparison to World Civilization, along with other regular subjects so that peace education can be enhanced in India's multicultural and multi-ethnic society.

All three thinkers spoke of education of science and technology and that is the need of the hour; but not being the slave of technology, otherwise humanity is at stake. Therefore though all three were Vedantins basically (those who believe in Monistic philosophy and the theory of Maya, that is 'world is illus/ion'; "none of our contemporary philosophers including Vivekananda, Tagore and Gandhi preached about the illusory nature of the world. They, on the other hand, emphasized that multiplicity is as much real as unity since the essence of Indian culture is unity in diversity" [Pathak, 2012: 93].

Our education system can do wonders if the 'intentional ethics' and 'ethos of the people' are combined together. As Aroon Tikekar says, "The liberal education was chiefly education in classical languages, classical literatures and the humanities which exposed to students the importance of the moral virtues and the human values in addition to one's chosen area of study. The intention was that students should imbibe freedom of mind, body and spirit; freedom from dogmas; freedom from superstitions and taboos, and also freedom to raise problematic and critical questions; freedom to disagree and freedom to choose vocation. Apart from these basic freedoms the other liberal values were supposed to be an unshakable belief in equality i.e. the conviction that all human beings are born equal and should be treated as equal; individual dignity i.e. the Right to respect and the Right to get ethical treatment; as also two more categorical imperatives, tolerance and non-violence. These 'liberal values' taught students basic principles in corporate living with a firm belief in 'live and let live"” [Tikekar, 2012: 07-08].

This long quotation from Tikekar's Ideas Matter sums up this complete article. The idea of ideal education that incorporates all basic human values mentioned in the above quotation is echoed in Gandhi, Vivekananda and Tagore's philosophy of education. The future is not bleak if we transfer these philosophers' ideas in our education system, indeed in new garb that is the need of the hour and for the future.

\section{References}

Ahmad, Tariq. Constitutional Right to an Education: India. Library of Congress, 2016.

Barman, Bablu. Swami Vivekananda's views on Philosophy of Education. International Journal of New Technology and Research (IJNTR), 2016, Vol.2, Issue 7: 106-108.

Bharathi, D. Vijaya and Rao Digumarti Bhaskara. Educational Philosophy of Swami Vivekananda. Discovery Publishing House, New Delhi, 2005.

Bharata, Prabuddha. Vivekananda, Kant and Modern Materialism. Calcutta Review, April 1939.

Bharathi, K. S. The Social Philosophy of Mahatma Gandhi. Gandhi Studies and Peace Research Series 4. Concept Publishing Company, New Delhi, 1991.

Chakrabarti, Mohit. Philosophy of Education of Rabindranath Tagore. Atlantic Publishers and Distributors, 1988.

Dasgupta, Santwana and Dasgupta, Bijaya. Vivekananda, the Prophet of Human Emancipation: A Study on the Social Philosophy of Swami Vivekananda. Calcutta, India, 1991. 
Dash, M. Education in India: Problems and Perspectives. Atlantic Publishers and Distributors, New Delhi, 2004.

Dewey, John. Democracy and Education: An Introduction to the Philosophy of Education. New York: MacMillan, 1916.

Encyclopedia Britannica. 2018. https://www.britannica.com/

Gandhi, M. K. Harijan. May 27, 1939.

Ghosh, Ranjan. Aesthetics, Politics, Pedagogy and Tagore: A Transcultural Philosophy of Education. Springer Nature, UK, 2017.

Kuriakose, Karikottuchira. Implications and Application of the Educational Philosophy of mahatma Gandhi to the United Nation's Literacy Program. Education, 1995.

Pathak, R. P. Philosophical and Sociological Principles of Education. Dorling Kindersley, Pearson Education, India, 2012.

Prathapan, Supriya. Swami Vivekananda's Philosophy of Education. (Philosophical Foundations of Education.) Philosopan, 2014.

Rather, A. R. Theory and Principles of Education. Discovery Publishing House, New Delhi, 2007.

Tikekar, Aroon. Ideas Matter. Rohan Prakashan, 2012.

Thriveni, C. Rabindranath Tagore's Philosophy of Indian Education. Eternal Bhoomi, 6 February, 2018. http://bhoomimagazine.org/2018/02/06/rabindranath-tagoresphilosophy-on-indian-education 